\title{
Trouble in Paradise: the 1958 white mineworkers' strike on the Zambian Copperbelt
}

Duncan Money

Text version of my article that was published in Extractive Industries and Society, 4, 4 (2017), pp. 707-16.

\section{https://doi.org/10.1016/j.exis.2017.07.005}

\section{Introduction}

Industrial unrest plagued the Copperbelt during the 1950s. The cluster of copper mines stretched out along the border between Zambia and the Democratic Republic of Congo was one of the largest copper producing regions in the world, with output reaching 417,000 long tons in 1959 , but production was regularly curtailed by strikes, both official and unofficial (Chamber of Mines, 1962). Industrial relations provided a near-constant headache for the two mining companies who dominated the region: Rhodesian Anglo American (RAA), a subsidiary of the South African mining giant Anglo American Corporation, and the Rhodesian Selection Trust (RST), a nominally British company largely financed from the United States. The focus of this article is on the longest Copperbelt-wide strike in the region's history, the bitterly contentious dispute over restructuring.

Restructuring workforces and industrial unrest remain highly contentious and pertinent issues in the mining industry, especially in southern Africa, and this article seeks to add a historical dimension to the relationship between the two. Although the history of industrial relations on the Copperbelt has often been seen through the lens of race, the issues underlying the 1958 strike were contestations over what constituted skill and who had authority over the organisation of work on the mines. Both notions of skill and authority were closely intertwined with race, as only white men were allowed to perform skilled jobs on the mines, yet the conflict in this dispute was not over race. Instead, this strike pitted white mineworkers against white employers over proposals 
from the latter to restructured the skilled white workforce, and, during the dispute, the white and the African mineworkers' union sought to cooperate against the mine management. By examining the 1958 strike, this article seeks to move understandings of the Copperbelt's mining industry and workforce beyond ideas of a binary racial conflict.

This was a dispute which quickly went beyond the workplace. The centrality of the mines to the towns that surrounded them ensured the strike was unavoidable and consequently there was a considerable community mobilisation around the dispute that both challenged and reinforced gender roles. There is a rich history of such mobilisation in the mining towns of southern Africa but this proved to be the last time that white mineworkers and white communities rallied on such a large-scale in the region (Krikler, 2005; Katz, 1976). The dispute also had a wider resonance beyond the workplace because the Copperbelt was the economic powerhouse of the Central African Federation, a short-lived union of three British colonies: Northern Rhodesia (now Zambia), Southern Rhodesia (now Zimbabwe) and Nyasaland (now Malawi). Recession and strikes on the Copperbelt could cripple the Federal economy, bringing its viability into question.

Scholars of the Copperbelt have been closely attuned to issues around restructuring and the re-organisation of work on the mines, but have focused on the restructuring which took place along racial lines: the removal of the colour bar and negotiations on 'African advancement' from the 1940s to the 1960s (Burawoy, 1972; Berger, 1974; Daniel, 1979, Mhone, 1982; Butler, 2007). Charles Perrings' contention that "work relating to changes in the division of labour in the post-war years has almost without exception focused on the 'issue' of African advancement" remains largely unchallenged (Perrings, 1980, 188). Somewhat surprisingly, much of the existing historical literature only touches on the role played by copper prices, though the region's fortunes were - and remain - tightly bound up with the fortunes of the mining industry. The work of lan Phimister remains an exception to this, though he uses changes in the cost structure and profitability of the mining industry to explain the timing of initiatives around African advancement (Phimister, 2011).

Stratified workforces, on lines of race and skill, with occupational hierarchies that privileged the importance of some industrial skills over others, such as rock-drilling, 
were commonplace in the copper mining industry elsewhere in the world (Lankton, 1991; Cancilla Martinelli, 2009). Moreover, these occupational hierarchies on the mines and attempts by the mining companies to alter these hierarchies - and the pay and social status associated with these hierarchies - often triggered industrial disputes (Stewart, 2013). On the Copperbelt, the most obvious hierarchy was the industrial colour bar which, from 1941, restricted virtually all skilled jobs and many semi-skilled jobs to men of European descent. All unskilled work was performed by Africans who constituted the large majority of the workforce (83\% in 1958) and undertook most of the manual work underground and on the surface: working as labourers, drillers, removing blasted ore, loading skips, etc. A smaller number held higher-status jobs which involved less manual labour including clerks and 'boss boys', who supervised African labour underground.

Within the racialized division of labour, the white workforce was itself divided along lines of skill and class into a daily-paid section and a monthly-paid staff section. Staff positions included clerical workers, professionals such as geologists and chemists, low-level managers along with supervisors of white labour: shift bosses, mine captains and planet foreman. Daily-paid mineworkers were mostly graded either as semi-skilled operators - jobs such as pipefitters, riggers, cage tenders, and banksmen - or artisans. Most of these jobs also involved supervision of African mineworkers, over whom daily-paid mineworkers had direct authority, yet this group had a strong selfimage that they were working-class. This was reinforced by the closed shop; all dailypaid mineworkers had to be members of the whites-only Northern Rhodesian Mine Workers' Union (NRMWU).

White mineworkers on the Copperbelt were effectively expatriates, even though they were often referred to as 'settlers' in colonial-era documents and in the subsequent academic literature. Recruited primarily in Britain and South Africa, the large majority stayed for only a few years - almost $50 \%$ of daily-paid mineworkers had been on the Copperbelt for less than three years in 1958 (Chamber of Mines, 1959) - and many had made careers moving between mining regions around the world. Despite different national origins, almost all white mineworkers were English-speaking. A 1959 survey of the white workforce found that $80.5 \%$ spoke English as a first-language, $9 \%$ spoke Afrikaans and 9\% were bilingual (Holleman and Biescheuvel, 1960, ii). There is however an important difference with contemporary expatriate workforces: the white 
workforce on the Copperbelt mines had a strong sense of collective interests. These collective interests, and a sense they were being threatened, regularly provoked industrial unrest, which itself encouraged transience in the white population.

There has however been little reassessment of the history of industrial relations on the Copperbelt in this period since the conclusion reached in the mining industry's own official history that "The story of industrial relations on the Copperbelt is largely the story of African advancement" (Roan Consolidated Mines, 1978, 72). This article will instead argue that the primary issue in this dispute was the attempt by the Chamber of Mines to re-organise work on the mines by altering and blurring the demarcation between skilled white artisans and semi-skilled white operators. White artisans regarded themselves as a labour aristocracy with firm ideas about what constituted 'their' work - work which could only be performed by a skilled, appropriately qualified artisan - and jealously guarded that work. The struggle to restructure their work overlaid a wider struggle about perceptions of skill, authority on the mines and ideas about the dignity of labour.

\section{Background to the strike}

1956 had been a year "of great prosperity and achievement" for the Copperbelt with output boosted to a record level as new mines came into production. Burgeoning production, both on the Copperbelt and globally, had been underpinned by the long post-war boom in copper prices (see Fig. 1). This came to a sudden halt as copper prices hit the "unprecedented figure of $£ 437$ a ton" in March 1956, and then plummeted to $£ 264$ in July, an "unprecedented" collapse in the history of the industry "both for magnitude and speed" (Chamber of Mines, 1957, 7). 
Fig 1: Copper prices and Copperbelt production, 1946-60

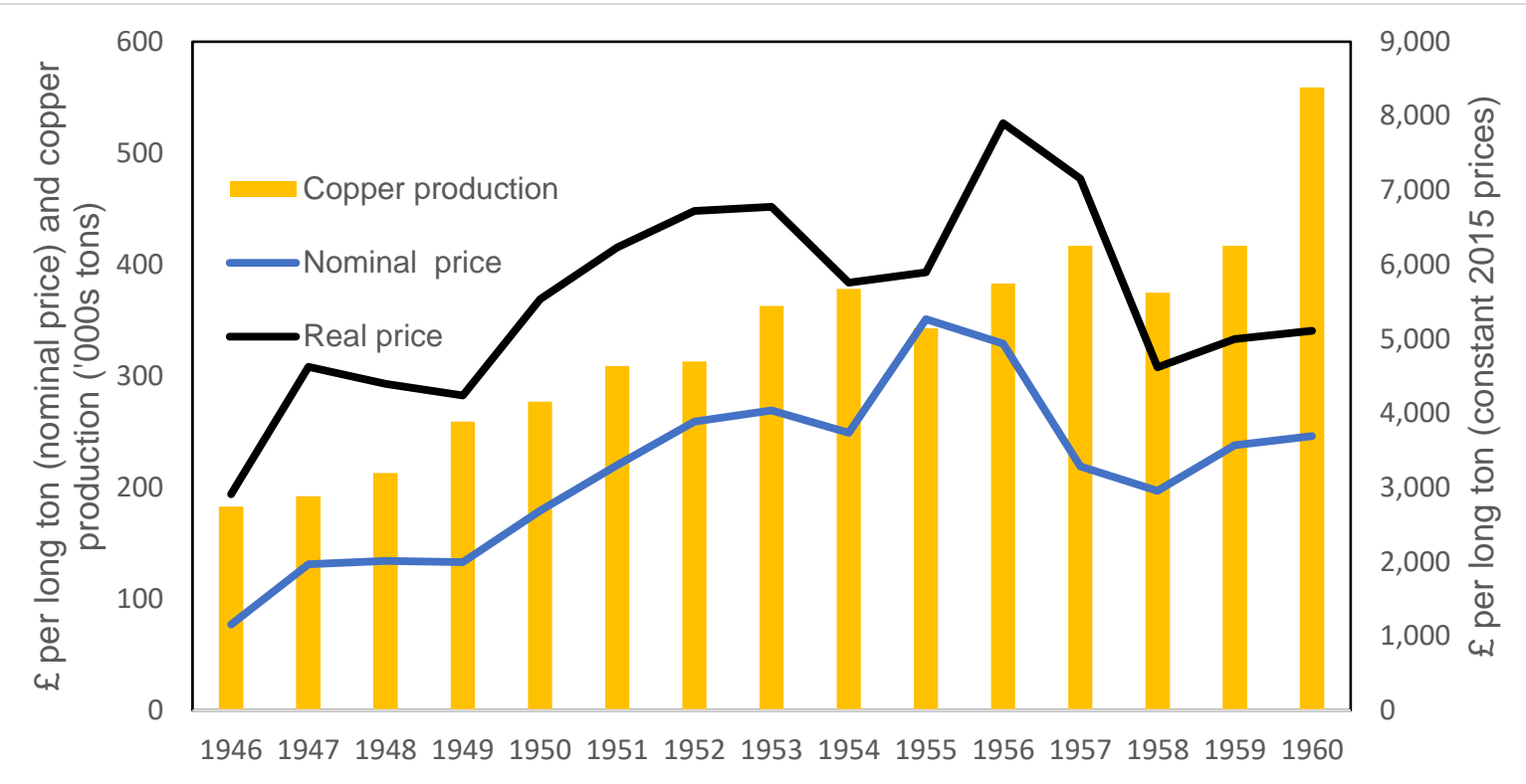

Source: Coleman, 1971; Cunningham, 1981

Copper prices collapsed at a particularly inconvenient moment for RST and RAA. Both had embarked on major expansions during the boom years: RAA was developing a new property, Bancroft Mine, while RST was greatly expanding Mufulira Mine through the Mufulira West Extension. Both companies had intended to finance these expansions through retained profits and issuing debt (Cunningham, 1981, 104-6; Phimister, 2011, 225). Cutting costs therefore became imperative and the companies sought to improve the productivity of their expensive white workforce.

White mineworkers had become more expensive and more numerous during the 1950s. Their basic wages rose by between 60 and 102\% (depending on the job) between June 1949 and January 1958, an increase of 12-39\% in real terms. This placed them in an extraordinarily privileged position compared to mineworkers elsewhere in the world. For instance, Anglo American calculated that wages on the Copperbelt were between $28 \%$ and $90 \%$ higher than wages for white employees doing similar jobs on its gold mines in the Orange Free State, South Africa (Bromwich and Davidson, 1958). The impact of rising wages was exacerbated by a steady increase in the size of the white workforce, both in absolute and proportional terms. The number of white mineworkers rose from 4,293 in 1949 to 6,739 by 1958 , and from $11.5 \%$ of the total workforce to $17 \%$ (Chamber of Mines, 1962). 
This growth of the white workforce was underpinned by technological developments and mechanisation - particularly underground with the introduction of trackless loaders to remove ore and electronic detonation to allow coordinated blasting - as skilled jobs could, under the stipulations of the colour bar, only be performed by whites. The impact of technological developments on the composition of the workforce can be seen in one of the major innovations of this period: the introduction of open-cast mining, following wider developments in the global copper mining industry (LeCain, $2009,15)$. In 1958, RAA acquired a bucket-wheel excavator for Nchanga Open Pit capable of removing about half a ton of overburden a second. The excavator could be operated by one white and four African mineworkers, with white artisans responsible for repair and maintenance (Coleman, 1971, 162). In contrast, development work underground was undertaken by a white rockbreaker overseeing drilling teams of 1220 Africans (Perrings, 1980, 193).

Wages were by no means the only expense related to white mineworkers for the mining companies. All white employees received a cost of living allowance, company pension contribution, holiday allowance, and subsidies for housing, power, and water. Even the lowest paid job (handymen) received minimum totally monthly emoluments of $£ 134$. For surface and underground artisans, the figures were $£ 156$ and $£ 162$ per month (Bromwich and Davidson, 1958). In addition, there was a percentage bonus based on the price of copper, which peaked at $102.5 \%$ of basic pay in 1955 (Berger, 1974, 183). It was, as one contemporary journalist remarked, "a paradise for the proletariat" (Dunn, 1959, 136).

Generous wages and conditions had however not bought a quiescent workforce and the recession in the mining industry, which had an immediate negative effect on their living standards, meant that white mineworkers were in no mood to compromise. Takehome pay fell by between $16 \%$ and $31 \%$ between June 1956 and January 1958, while the copper bonus hit a decade-low of 17\% in June 1958 (Berger, 1974, 183; Bromwich and Davidson, 1958). Wage levels for artisans fell back to 1953 levels (see Fig. 2), while the cost of living for whites on the Copperbelt had risen by around $17 \%$ between 1953 and 1958 (Central Statistical Office, December 1963). Moreover, the prospect of mass redundancies loomed large over the Copperbelt, especially after Bancroft Mine ceased production in March 1958, and the number of daily-paid white mineworkers fell from 4,450 in 1957 to 4,082 in 1958. 
Figure 2: Surface and underground artisans' take-home pay, 1949-January 1958

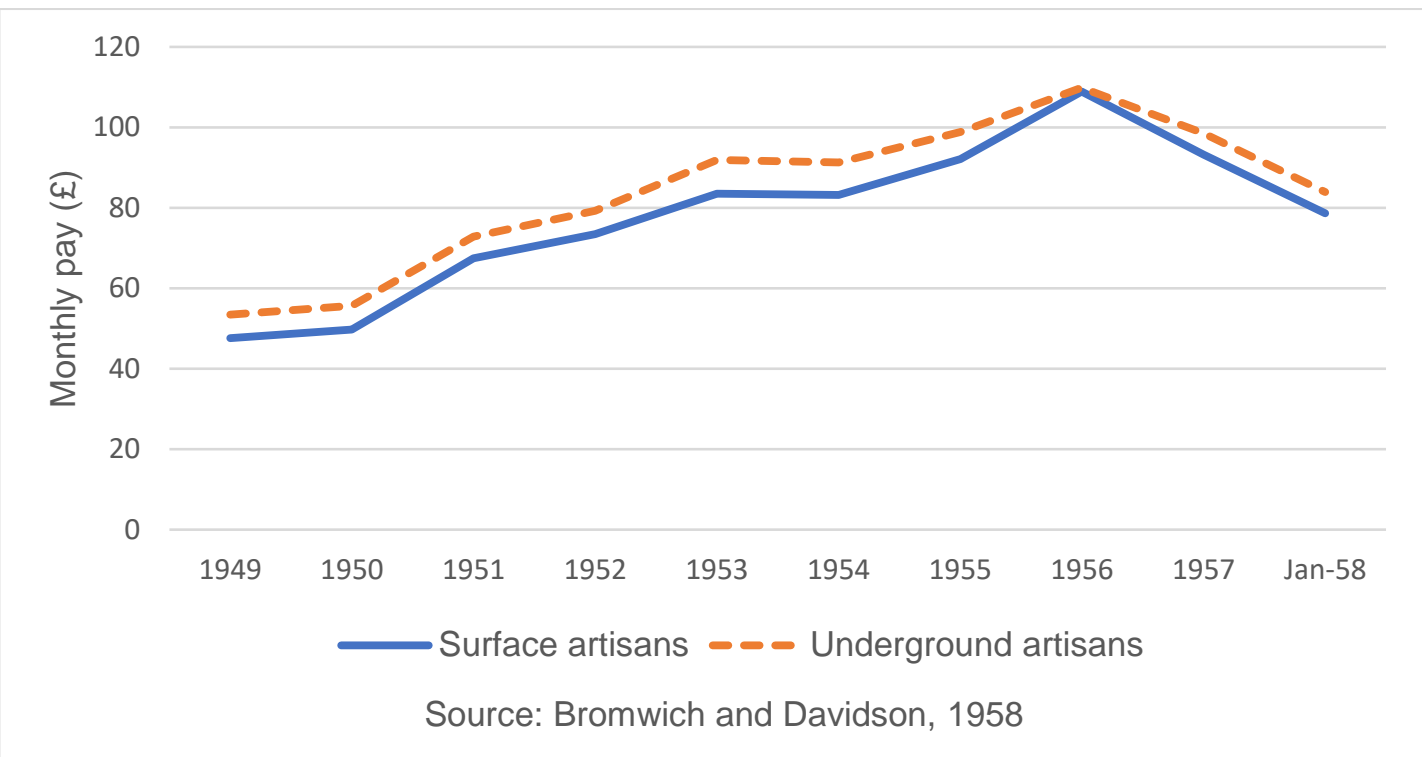

The first response to the recession, however, came from African mineworkers, who were hardest hit. The immediate cause of a wave of escalating strikes in mid-1956 was the restructuring of the African workforce. This issue had been simmering since June 1955 when the mining companies had introduced monthly pay for African mineworkers in supervisory jobs. The move to staff status - replicating the division in the white workforce - was initially voluntarily imposed on the workers concerned but it involved a pay rise and, crucially, made them ineligible for membership of the African Mineworkers' Union (AMU). Instead, a group of new African staff formed the Mines African Staff Association (MASA) (Berger, 1974, 149).

The AMU regarded the establishment and recognition of MASA as an existential threat, one aimed at effectively decapitating the union by removing the more skilled and educated members from its ranks (Larmer, 2007, 36). A strike in June 1956 over the recognition of MASA was followed by an announcement from both mining companies that transfer to monthly pay would be mandatory for African mineworkers in the relevant categories. The AMU was determined to halt this and dramatically intensified their efforts. Rolling strikes hit every mine on the Copperbelt, one after the other, from 30 July, causing massive disruption. As African mineworkers returned to work at one mine, they walked out at another. On 11 September, the colonial government declared a state of emergency. After another Copperbelt-wide strike from 14 September, most of the AMU leadership was arrested, removed from the 
Copperbelt and restricted to remote rural areas, where some were held for over two years (Colonial Office, December 1958).

Following defeat in the strike and the forced dispersal of much of its leadership, the AMU almost collapsed. Membership fell to around 6,500, out of a total African workforce of over 38,000, placing the union in dire financial straits (Berger, 1974, 161). It was unable to prevent the forcible introduction of staff status or resist mass redundancies, and consequently the African workforce was reduced by almost 6,000 during 1957 (Chamber of Mines, 1962). In the aftermath, the union's more moderate general secretary, Lawrence Katilungu, who been out of the country during the State of Emergency and was not arrested, consolidated his hold over the AMU. Defeating the AMU made the mining companies more confident they could restructure their expensive white workforce.

The Copperbelt saw less than three months' industrial peace before a wildcat strike by white mineworkers shut down Bancroft Mine for most of December 1956. This turned out to be the first of nine wildcat strikes by white mineworkers, culminating in a Copperbelt-wide shut-down in July 1957 when rockbreakers' tried to unilaterally reduce their working week by two hours. Tellingly, none of these strikes arose over the colour bar and all began over minor incidents that escalated rapidly, reflecting the tense situation on the mines. The most common cause - which triggered four of the strikes - was poor relations between daily-paid mineworkers and mine officials. Others were related to sackings, dangerous conditions, contract rates, a demand for a new hospital, and the demarcation of artisans' work (Honeyman, 1957).

Industrial unrest seemed near-constant on the Copperbelt, as Northern Rhodesia's Governor Arthur Benson complained:

During the past four-and-a-half years as Governor here I doubt if a single day has passed when I have not been personally involved in consideration of some aspect of the relationship between master and man, and the inter-play between various Unions and the Management, on the Copperbelt (Benson, 11 November 1958).

\section{Restructuring negotiations}

When it became clear that the fall in copper prices was not a temporary dip, both RAA and RST began seriously investigating measures to reduce production costs. In 
September 1957, the Chamber of Mines appointed a sub-committee to make recommendations on the rationalisation of white labour. If the companies did not already have enough incentive to pursue this, that same month, the NRMWU began pressing for a $15 \%$ wage increase for all its members. In January 1958 , as copper prices headed for their nadir of $£ 166$ a ton, the companies presented the white employee organisations with several measures intended to boost productivity, including the more regular use of contractors and shifting the demarcation of work between artisans and non-artisans (Chamber of Mines, 12 September 1958).

Artisans were skilled manual workers who occupied a crucial position in the running of the mines and jealously guarded 'their' work. Their jobs on the Copperbelt were restricted to white men who had completed an apprenticeship. Most artisans on the Copperbelt had completed apprenticeships elsewhere in the world but each mine took on a group of apprentices annually. Apprentices were usually teenagers, at least 15 years old, and spent five years in training on the mine with annual government trade tests before the apprenticeship was complete. It was common for apprentices to join the same trade as their father, in effect being born into the trade. NRMWU General Secretary Jack Purvis had for example been apprenticed as an electrician on the Copperbelt, the same job as his father Jim Purvis, who had begun his working life in the small copper-mining town of Nymagee, Australia.

Apprenticeships not only denoted that a worker had the appropriate level of skill and judgement that the work required but also constituted a formal line of demarcation. Artisan was a designation that embodied both a considerable amount of pride in the work they performed and a determination to prevent those who were regarded as unskilled performing 'their' work. New artisans who started work on the Copperbelt mines had to present papers to the union's Artisan's Sub-Committee confirming they had served an apprenticeship. Artisans who failed to produce such papers were expelled from the union and consequently lost their jobs.

The mines' initial isolation from secondary industries ensured that the type of maintenance and construction work that was undertaken elsewhere in the world by contractors had to be done 'in house', so a wide array of artisans were employed on the mines. Arbitration proceedings following a strike by artisans that had taken place in 1944 covered: 
blacksmiths, boilermakers, bricklayers, carpenters, drill-makers, electricians, fitters, garage mechanics, masons, moulders, painters, patternmakers, plumbers, riggers, rockdrill fitters, sawdoctors, sawyers, tinsmiths, tool and diemakers, turners, welders, and leadburners (Chamber of Mines, 4 October 1944).

The same array of artisans and the kind of jobs they performed on the mines remained the same 14 years later, though the companies had regularly chafed against what they termed 'restrictive practices' in the intervening period. For instance, a strike by underground artisans on Mufulira Mine, over an allegation that a timberman had done artisans work, prompted a bitter complaint from the mine's personnel manager that "that once an artisan touches a job, it thereafter becomes sacred to the artisans" (Mufulira Mine, 19 August 1955).

What the companies termed 'efficiency measures' comprised of 106 tasks performed by artisans which they sought to hand over to semi-skilled white operators as well as plans to make more extensive use of contractors on the mines. It is worth noting that the companies had no plans to engage in a wholesale restructuring of the racialized division of labour. Artisans' jobs were vulnerable to be restructured as they normally performed both complex and simple work as part of their daily tasks. Fitters, for instance, had to be able to undertake repair and maintenance work on almost all equipment used on the mines, from hospital equipment to hoists on the main shafts. They had to be able to perform complex tasks but much of their time was spent on relatively simple repair work. Under the proposed efficiency measures, operators would perform less complex repair work.

Reception of the 'efficiency measures' among the white workforce was decidedly mixed. The Mine Officials and Salaried Staff Association (MOSSA) "assured the Companies that they would support the Companies in implementing the measures" after brief negotiations (Chamber of Mines, 31 March 1958). There was a clear class division here as the geologists, chemists and mine officials who constituted the membership of MOSSA would be unaffected by these plans. The NRMWU, unsurprisingly, resolutely opposed the changes. The union eventually concluded that artisans' jobs would be fragmented so there would "in the near future be very few artisans employed in their proper capacity." Instead, "these artisans will be given 
alternative employment as operators at a very much reduced rate of pay" (NRMWU, 17 October 1958). Operators, meanwhile, would have to do more work for the same rate of pay.

There can be no doubt though that militancy among the white workforce was driven by more skilled workers among the NRMWU membership. Six of the nine wildcat strikes that took place from December 1956 were initiated either by artisans or rockbreakers, one of the highest-paid jobs on the mine (Honeyman, 1957). Moreover, the NRMWU leadership in 1958 included three rockbreakers, two electricians, a hoist driver, but only two men in semi-skilled jobs (NRMWU, 29 September 1958). The militancy of the union's leadership shocked the British Trade Union Congress (TUC) representative sent to advise them. Their bellicose statements of 'beating the bosses to their knees', he reported, "give the impression that we were living in 1926," the year of the British general strike (Hood, 8 September 1958). This militancy however reflected the fact that this restructuring affected most of them personally and their own jobs cannot have been far from their minds during negotiations.

Seven months of negotiations slowly reduced the number of restructured tasks from 106 to 22. These, however, represented the most substantial alterations to existing work practices, and became known as the 'disputed jobs'. The demarcation between artisans and non-artisans was considered to be of crucial importance by both sides. The "use of a cutting torch" was, the Chamber of Mines felt, "a vital point of principle," as it was "a common tool" that should be available for any white mineworker to use and not a specialised piece of equipment reserved only for artisans (Chamber of Mines, 1 July 1958). Talks hit a deadlock in July after union representatives refused to accept any further changes to artisans' jobs or to allow contractors to undertake more work on the mines, which they viewed as the introduction of non-unionised white labour. The Chamber of Mines abandoned negotiations and announced that all 22 disputed jobs would be implemented from 1 August (Chamber of Mines, 22 July 1958).

On 3 August, around 160 shop stewards met in Kitwe and formulated an unambiguous response: "The Union should resist with every means in its power" the efficiency plans and should press forward with efforts to secure a 15\% wage increase (Northern News, 4 August 1958). This was a clear threat to strike but the shop stewards' resolve wavered when they returned to the mines. For the next week, the Rhokana and 
Nchanga branches vacillated over declaring an overtime ban after RAA threatened to close Rhokana Mine in response. Instead, they took what would previously have been the highly unusual step of consulting the AMU over the decision and decided not to proceed (Northern News, 12 August 1958).

The relationship between the AMU and NRMWU during the strike was ambiguous. Earlier in the 1950s the unions had been decidedly hostile toward each other, unsurprisingly given the NRMWU's defence of the colour bar. The recession in the copper industry, and encouragement from allies in the international labour movement, prompted officials from both unions to establish a liaison committee in February 1958. The committee meet regularly during most of the year and members attempted to formulate a common response to issues that arose on the mines, such as a joint union representation for white and African mineworkers sinking new shafts at Mufulira Mine. They also bonded over mutual antipathy toward the staff associations (NRMWU, 24 May 1958).

Meetings of the Liaison Committee became more sporadic in the run-up to the strike. Beyond the small number of union officials, the African and white workforce generally exhibited a strong sense of mutual detachment from each other. They conducted industrial struggles separately and there was no sense they faced a common opponent in the form of their employers. In 1958, as previously, white mineworkers acted more or less without consideration of how their actions would impact the African workforce, even though shutting down the mines would throw thousands of African mineworkers out of work with no pay. Indeed, by 25 September, almost 22,000 African mineworkers had been laid off as a result of the wildcat strikes (Colonial Office, 25 September 1958).

For their part, AMU officials demanded that the mining companies continue to pay their members laid off during the strike, on the grounds that they were prevented from working by a strike they were not involved in and which did not concern them. Yet AMU officials also repeatedly voiced support for one of the NRMWU's main demands: the creation of industrial courts with the power to enforce compulsory arbitration for the mining industry (Northern News, 9 September 1958). NRMWU officials, for their part, assisted the AMU in pursuing its wage claim against the companies as a way of inflicting major financial damages on the mining companies at little cost to its own members (Colonial Office, September 1958). Paying for African mineworkers laid off 
without notice by the strike would have cost the companies around £572,000 a month (Northern News, 16 September 1958).

Managers on all mines began ordering white operators to perform the disputed jobs in early August. In response, on 12 August, instructions were issued to all NRMWU members that they should refuse to perform any of the disputed jobs and emphasising the existing rules that "no artisan's work shall be carried out by an employee other than an artisan" (NRMWU, 12 August 1958). This was reiterated later that month with the additional warning: "Members of the Union who do not comply with this instruction will render themselves liable to disciplinary action" (NRMWU, 28 August 1958). Union members were placed in a difficult position. Disciplinary action could mean expulsion from the union and, under the provisions of the closed shop agreement, any daily-paid mineworker expelled from the NRMWU lost their job. Yet refusing to obey a direct order from a shift boss or foreman would likely result in instant dismissal, as began to happen almost immediately. The first daily-paid mineworker - a timberman who had only been on the Copperbelt for 18 months - was sacked from Mufulira Mine the day after the union notice was posted (Northern News, 15 August 1958). This began a steady stream of dismissals. Over the next 30 days, 62 men were sacked for refusing to obey direct orders.

What was at stake were competing notions of what constituted skill and the issue of authority on the mines. White artisans insisted on the uniquely skilled nature of their work and were infuriated by what the companies termed "the extreme and obvious simplicity of all" the disputed jobs (Chamber of Mines, 11 September 1958). Articles attacking artisans' conception of skill appeared in the territory's main newspaper, The Northern News, which was 'relied upon as the 'news agency' for the Chamber's statements and propaganda" (Chamber of Mines, 15 November 1958). "In three minutes today - without a spanner - I did the job... which concentrator operators have been barred from doing by the European Mineworkers' Union" claimed "A Woman Reporter", with the obvious implication that no job that could be performed by a woman was especially skilled (Northern News, 8 September 1958).

Dismissals placed a growing and unsustainable financial burden on the union, as it paid £5 a day to each man sacked (NRMWU, 17 October 1958). The union leadership was also struggling to keep a lid on the growing anger of its membership. On 3 
September, a 700-strong meeting at Nchanga Mine resolved to walk out as soon as the next man was sacked, and hundreds of men gathered the next day before the morning shift ready to block the shaft. Only the pleading of Jack Purvis that they obey the law halted the action (Northern News, 5 September 1958). An unofficial go-slow had already begun at Chibuluma Mine after pictures of tortoises were posted around the mine in response to the sacking of Jimmy Ryan, a timberman and local branch chairman, on 1 September for refusing to perform what he considered artisans' work (Northern News, 2 September 1958).

Progress through negotiations seemed increasingly unlikely. The two sides could not even reach an agreement over what they disagreed about. The Chamber of Mines claimed that 22 jobs remained unresolved, the NRMWU claimed there were 23 (Chamber of Mines, 29 August 1958). Sections of mines had begun to shut down as white mineworkers refused to obey instructions from underground managers and were then fired. Amidst rising tempers, the NRMWU balloted for strike action on 10 September and over $90 \%$ of daily-paid mineworkers on every mine voted to walk out two days later (Chamber of Mines, 10 September 1958). The anger at the treatment meted out to white mineworkers was palpable. The Chamber of Mines, the NRMWU claimed, wanted to inflict humiliation on "our members who were sacked. The Chamber wants to rub their noses in the dirt... Now we must stand and fight. There is no other way out" (Chamber of Mines, 16 September 1958).

Strike action sharpened class divisions among the white workforce as real bitterness developed between mine officials, who remained at work, and daily-paid mineworkers. Action was motivated by the occupational hierarchy on the mines, , even when the daily-paid mineworkers' perception of their place in the hierarchy was at odds with reality. Daily-paid mineworkers, despite their high wages and racially-based privileges, had developed a self-image as the downtrodden underdogs. For instance, one Nchanga striker suggested efficiency measures could be achieved by sacking mine officials since many did no real work, rather than targeting the "lower income group on the mines." This is indicative of the sense of detachment from the African workforce as the "lower income group" is not a reference to African mineworkers, who of course received much lower wages than white daily-paid mineworkers. Instead, the "infinitesimal" privileges of daily-paid men were compared upwards to mine officials, not to African mineworkers. The mines paid the wages of African domestic servants 
for officials, the striker from Nchanga claimed, whereas "At least the daily-paid man hired his own garden boy to cut his hedge" (Northern News, 16 October 1958).

The self-image of daily-paid mineworkers as underdogs engaged in a desperate struggle was also one that resonated outside the region as there was significant international mobilisation to assist the Copperbelt's white mineworkers. Officials from the British TUC and the Miners' International Federation, who were themselves former miners, were sent to the Copperbelt to advise the NRMWU and played an active role in the dispute. NRMWU members were despatched to South Africa, where they successfully secured support from the Trade Union Council of South Africa (TUCSA), who sent a delegation to lobby Anglo American in South Africa and appealed to its affiliates to donate the strikers' benevolent fund. The strike evidently resonated in South Africa as donations arrived from an array of white trade unions (TUCSA, 22 October 1958).

\section{Community mobilisation}

Every dispute on the mines had a major impact on the towns in which they were located. These towns were racially segregated along the same lines as the mines' workforce. This produced a four-way, unequal split: the white and African townships were themselves divided into a government township and a larger mine township. The mines dominated the towns. In 1961, over 55\% of all white employees in Bancroft, Chingola, Kalulushi, Luanshya, and Mufulira were employed directly on the mines. Even in Kitwe, the commercial and administrative centre of the Copperbelt, mining was still the largest occupational category, though Rhokana Mine only employed $26 \%$ of white employees in the town (Kay, 1967, 140).

Most of those who were not directly employed by the mines were thus dependent on them as many businesses relied on the sizeable disposable income of white mineworkers or on contracts from the mines. Businesses suffered as paying customers dwindled and they were pressed to extend credit or make donations to the union's strike fund. The extent of this dependence was revealed when, six weeks into the strike, almost 200 businesses from across the Copperbelt sent telegrams to the Federal Government demanding immediate state intervention to the end the strike because many were facing bankruptcy (Northern News, 22 October 1958). 
The dispute sharply divided opinion in the Copperbelt towns. One white resident called for the NRMWU to be crushed and its members ejected from the mines so the industry could "start afresh, and leave the efficient running of the mines to the owners, who know best" (Northern News, 3 September 1958). Seemingly incessant industrial unrest produced exasperation among others, who expressed anger at both sides. As the strike began, one Luanshya woman exclaimed that "it is about time that the members of the Chambers of Mines and the Mineworkers' Union behaved like adults" and blamed "perpetual threats of close-downs and strikes" for creating a state of insecurity that prevented the development of a settled white population (Northern News, 12 September 1958).

Divisions over the strike extended into the ranks of the NRMWU and it is clear that not all white mineworkers sought a bitter confrontation with their employers (as Miles Larmer has pointed out, there has been a "depressingly common tendency to characterise unionised mineworkers as a single homogenous unit" (Larmer, 2007, 4)). Some white operators resented being dragged into "irresponsible and unnecessary" strikes by the better-paid and more skilled workers, and briefly established a 'revolt group' to discourage strikes (The Guardian, 17 August 1957). The most serious dissenters however argued that the union was fighting the wrong opponent. Some mineworkers found it maddening that they were mobilising to prevent restructuring at a time when African nationalist movements were threatening the foundations of colonial rule. It was on this basis that one union member called for an immediate return to work because the "dispute is of such a minor nature" while "we are struggling to defeat repeated threats against white supremacy and, indeed, are facing severe competition from the African" who performed most skilled work anyway (Northern News, 21 October 1958b).

These were however a decidedly minority view among the wider white community. "I think it is the only way. If we don't stick together now we have had our chips" argued C.A. van Sladden, one of twelve women asked about the strike while out shopping in Kitwe. The other eleven agreed. R.M. Brown, whose husband was an artisan at Roan Antelope Mine, thought "to stand firm was the only answer, despite hardship for most families. If we let them down now it will break the union." One woman whose husband had not worked on the mines for several years declared she was "wholeheartedly 
behind it [the strike] and behind the union's principle" (Northern News, 18 September 1958).

Unlike many other mining regions - such as in neighbouring Katanga (Vanthemsche, 2012, 280) - there was not a pronounced gender imbalance among the white population on the Copperbelt. The 1956 census enumerated 16,014 white men and 14,251 white women in the region (Central Statistical Office, 1960). Almost all these white women were directly affected by the strike. Most mineworkers were married and their wives and daughters were involved in the strike from the outset organising campaigns to raise funds and raise the morale of striking men or berating opponents of the strike and waverers in letters to the press. In this sense, white women performed a similar role to the wives of African mineworkers on the Copperbelt who, during strikes by African workers, had publicly ridiculed opponents of the strike and pressured any vacillating husbands to back the AMU (Parpart, 1986; Sakala, 2011).

The issue of restructuring was taken seriously. One mineworkers' wife - who adopted the pseudonym 'Can Take It' and claimed her father had been jailed after the 1922 Rand Revolt - vowed she would "rather struggle" than complain "because our men must win this issue" and warned:

The sooner the so-called collar and tie group get together and decide which side they are on the better. The name of scab goes from generation to generation... The old scab taking down the skip, etc., may have a real nice job for future years, but just remember, scab, it is not your life you should think of but your children's to follow."

She had no doubt the strike would be won, but only "thanks to a crowd of good, solidbackboned women" (Northern News, 27 September 1958).

This feeling was given organisational expression on 1 October when a group of miners' wives formed the Women's Action League, headed by Rachel Mostert. "Wives," Mostert announced, "would be prepared to accept the hardship of continuing the strike, for weeks, if necessary" to win. In many ways, this group was like the miners' support groups that developed into Women Against Pit Closures during the 1984-85 British miners' strike, which took on a political role as well as providing material support (Stead, 1987). The Women's Action League's inaugural meeting sent a telegram to 
the Federal Governor General demanding the immediate establishment of arbitration courts for the mining industry, one of the demands of the NRMWU leadership (Northern News, 3 October 1958). The Women's Action League was the first body directly organising white women's support for the strike, which prior to this was uncoordinated, but it was likely formed in opposition to the new Housewives League. The latter League was a smaller group which sought to persuade men to return to work immediately (Chamber of Mines, 24 September 1958).

The Women's Action League aimed to bolster support for the strike among families who felt they had been hit hard but could not admit it. High wages for white mineworkers had created a culture of conspicuous consumption on the Copperbelt where having and spending money was valued. Reflecting on the strikes and recession, one local car dealer noted that even though most vehicles were bought on hire-purchase agreements, repossession was very rare: "People would live on breadrolls and meat pies, but would hang onto their cars at all costs" (Holleman and Biescheuvel, 1960, 32). One woman admitted at a League meeting that she was too proud to apply to the union's distress fund as "I would rather starve than beg for charity and there must be hundreds of other wives like me" (Northern News, 9 October 1958). This then increased household pressure for male strikers to return to work. To overcome this, League members went door-to-door collecting food and cash from white households not on strike and from local businesses, then left food parcels quietly on doorsteps. As Mostert explained, "Rather than embarrass them, we are just leaving the parcels at their doors - like Father Christmas" (Northern News, 18 October 1958).

This is one indication of the way industrial disputes could have an unsettling impact on gender relations. Strikes could reinforce a strong, masculine self-image of men taking on a powerful foe in support of a just cause. Moreover, as Carolyn Brown has argued in relation to disputes by Nigerian coal miners, demands for good wages and "respectful working conditions" could be closely linked to "the material and ritual requirements of male status" (Brown, 2006, 37). Yet strikes could also undermine the masculine ideal of white men as hard-working breadwinners providing for their families, as families were forced to accept food parcels. Many white women pressured men to support the strike initially but, as it became clear this would not be a short dispute, disquiet over money grew. One woman claimed that "the majority of wives cannot afford to have their men out of work for a week, let alone an indefinite period" 
so should return to work (Northern News, 1 October 1958). There were few active roles for male strikers to perform during the dispute. Unlike the classic images of miners' strikes in Britain, with mass pickets and pitched battles, there was no need to picket to shut down shafts or surface plants as no daily-paid mineworkers even attempted to resume work. Instead, much of the everyday work of the strike was collecting and distributing money and goods, tasks that often fell on women.

The NRMWU had sought to publicly mobilise the white community intermittently during 1958 in support of its demands. On May Day, they had organised a show of strength in Kitwe with a march of 4,000 white residents followed by a rally on a local football field, where a collection raised $£ 1,000$ for the union (Rhokana Review, June 1958). More concerted efforts to mobilise union members and the wider community were only made after the strike began. At the outset of the strike, for instance, the Roan Antelope NRMWU branch established an entertainment committee "to overcome 'Copperbelt Boredom' - you know. Nowhere to go - nothing to do - nothing to see." Free film screenings, dances, and a talent contest were arranged. Social occasions, and the newsletter advertising them, were used to provide updates on strike developments and push the union's case (Roan Branch, 19 September 1958).

As noted above, the NRMWU struggle to provide strike pay and instead issued vouchers to be exchanged at local stores for essential goods. Union branches also began bulk-buying meat to provide members with cheap beef and arranging 'strike discounts' with local businesses (Roan Branch, 7 October 1958). At Rhokana, the branch began issuing ration sheets to distribute food parcels according to need, while Nchanga branch issued free meal tickets at the mine mess. Roan Antelope formed a sub-committee of miners' wives to collect fruit and vegetables from gardens and to work out ways to reduce the cost of living (Roan Branch, 22 October 1958). Again, there were strong parallels to events during strikes by African mineworkers' in the 1950s, during which African women grew and collected food to sustain the strike (Parpart, 1986, 50).

Branch committees supplemented the efforts of the Women's Action League who, by late October, were collecting and distributing 200 lb of meat, 100 bread loaves, 144 eggs and five-gallons of milk every week in Kitwe alone (Northern News, 28 October 1958). Real hardship was passed on rather than endured, however. Strikers were not 
prepared to dispense with African domestic servants, who were present in almost all white householders. With money tight, domestic servants in Kitwe worked without pay. "My boy is working for his food only," Mostert claimed, "and committee and league members report the same" (Northern News, 13 October 1958). Hardships suffered by African domestic workers, like African mineworkers laid-off by the strike, aroused little concern among the white community. Most white mineworkers considered themselves and their struggle first and foremost, with Africans effectively regarded as bystanders.

\section{Defeat of the strike}

Daily-paid mineworkers performed jobs essential to the functioning of the mines - such as operating winding engines on all shafts - and all mines had therefore quickly shut down at the beginning of the strike (except Bancroft Mine which had already ceased production and where some development work continued). Yet from the outset, the NRMWU leadership was not confident of securing victory through strike action alone. The timing of the strike had given the mining companies the upper hand. While copper prices remained low, RAA and RST were both willing to sit out even a lengthy strike to restore managerial authority. Instead, the NRMWU focused its efforts on securing state-backed compulsory arbitration for disputes in the mining industry, in which both parties would have their claims assessed and adjudicated by a state-appointed arbitrator whose ruling would then be binding. Both mining companies resolutely opposed this, but the union sought a strike lengthy and damaging enough to change their minds as defeat would be disastrous, and final. In the closing days of the strike, Jim Purvis warned that it would be "the final showdown between the men and the mining companies... paupers versus the millionaires" (Northern News, 29 October 1958a).

Efforts to make the strike lengthy and damaging focused on making the provision of essential services costly and difficult. Some work had to continue even when the mines were closed. Pumps had to be operated to prevent underground workings from flooding, the main haulages needed to be inspected to check for collapses, construction work was required to repair supports, and the main shafts had to be operated to carry men and materials. However, RAA had requested what looked like a suspiciously high number of daily-paid mineworkers for essential service on two mines they operated: 153 at Rhokana Mine and 143 at Nchanga Mine, while there 
were only 47 daily-paid mineworkers on essential service at Roan Antelope Mine and 33 at Mufulira Mine (Colonial Office, 25 September 1958). NRMWU officials believed that these mines were attempting to restart production, with daily-paid men on essential service freeing up enough white mine officials to resume production with African mineworkers.

Shop stewards therefore demanded the right to decide what constituted essential work, in what was essentially an extension of their claim about skill and authority in the mines. They, and not mine officials, had the skills and experience to adjudicate on essential work. Shop stewards began logging details of mine officials entering the mines, asking them their name, purpose and what equipment they had. These actions were bitterly resented by officials; exactly the desired response. A shop steward at Roan Antelope explained that they realised the consequences of their actions but had made no mistake. The officials had been scabbing so "they were deliberately trying to get their own back by antagonising them as much as possible." Roan Antelope's mine superintendent was incandescent at this: "We, and not the Union, ran the Mine" (Roan Antelope Copper Mines, 18 September 1958). MOSSA, for its part, furiously rebutted allegations that their members attempted to restart production during the strike and condemned the actions of NRMWU shop stewards: "Once an official has decided that work is essential," their general secretary declared after the strike, "no shop steward has the right to over-rule them" (Handford, 19 April 1959).

Efforts to disrupt essential services did not weaken the resolve of RST and RAA to resist any meaningful concessions to the strikers. This was an attitude guided by the international experience and contacts of key individuals in both companies. For instance, RST chairman Ronald Prain's conviction that it was necessary to take a hard line during the 1958 strike was informed by what he regarded as his "considerable experience of the labour conditions today in some of the main mining countries such as Chile, Mexico, the United States and Canada, with all of which I am closely connected" (Prain, 10 December 1958). The same international contacts informed the companies' decision to reject any possibility of compulsory arbitration.

The strike was however slowly crippling the Federal economy, which was heavily dependent on copper. Crisis loomed and one Federal MP even demanded that the Government declare "a state of emergency and for the Government to order miners 
back to work" (Northern News, 21 October 1958a). Yet the Federal and the Northern Rhodesia Governments declined to intervene and repeatedly rebuffed appeals to introduce compulsory arbitration or other mechanisms to force a settlement. This is one indication of the balance of power between the two mining companies and local governments. RST was particularly opposed to state intervention as they argued it would have "harmful long terms effects on the industry" because "in our view habitual Government interference in our affairs must eventually lead to virtual control of the industry by the Union" (Roselite Salisbury, 22 October 1958). The Federal Government was elected by an overwhelmingly white electorate and, in theory, the Copperbelt's white mineworkers formed a powerful voting bloc. However, many NRMWU members had not been resident on the Copperbelt long enough to be eligible to vote in the November 1958 Federal elections, and, in a reflection of their transient nature, only a minority of those eligible were registered to vote (NRMWU, 29 September 1958).

White mineworkers' resolve was disintegrating by late October. "I, for one, cannot go on indefinitely - heading for ruination as every day passed" exclaimed one Mufulira mineworker (Northern News, 31 October 1958). Queuing at the union office to buy cheap meat was not the kind of life whites had travelled to the Copperbelt for. NRMWU members at Mufulira voted on 29 October to return to work but mass meetings at Nchanga, Nkana, and Roan Antelope voted heavily against any return (Chamber of Mines, 29 October 1958). The mood was clearly shifting in the Copperbelt towns though. Rival petitions on the strike were circulated. One, drawn up by two women in Luanshya, called for intervention from Northern Rhodesia's Governor to end the strike, and had been rapidly signed by 500 women. The other was organised by the Women's Action League and also directed at the Governor, but asked him to introduce compulsory arbitration through emergency legislation and attracted far fewer signatures (Northern News, 29 October 1958b).

The Governor repeatedly refused to consider compulsory arbitration. This refusal left NRMWU officials searching desperately to secure any resolution to the dispute other than total defeat. Government-brokered meetings eventually produced some concessions: the companies agreed to reinstate all men sacked and to review the procedure for handling disputes. In return, the NRMWU effectively agreed that the remaining disputed jobs would be implemented after some perfunctory further 
negotiations (Chamber of Mines, 3 November 1958). At mass meetings branch chairmen "pleaded desperately with their members" to accept this deal and, by a show of hands, a large majority did. 2,616 voted to return to work, over 1,000 abstained and only 333 voted to continue striking (Northern News, 4 November 1958). After 53 days, the strike was over.

\section{Conclusion}

The strike was a near-total defeat for white mineworkers and the Chamber of Mines consequently sought to press home their advantage. In the weeks that followed, Chamber representatives suggested that their new objectives should be to "Chuck out the old guard" and "To rewrite the [union recognition] agreement to our entire advantage" (Chamber of Mines, 25 November 1958). The strike would be, as Prain put it, "but the first instalment of what may be a long series of recovering actions" to restore managerial authority (Prain, 10 December 1958). The Chamber's first objective was achieved by default with turnover of the white workforce reaching $36 \%$ in 1958 , and thousands of whites left the Copperbelt. Departures began even before the strike broke out and these workers dispersed far and wide. The number of people leaving Roan Antelope Mine for New Zealand, for instance, prompted the mine's official magazine to ponder "Wonder what's going on over there?" (Roan Antelope, August 1958). The continuation of high wages on the Copperbelt however ensured that new recruits were attracted as quickly as other white mineworkers departed. When the restructuring went ahead, it took place with a substantially reconstituted workforce.

Although the correct demarcation of artisans' work may seem a marginal concern today, this article has demonstrated how seriously union officials, white mineworkers, and their families regarded the issue. Attempts to alter and defend existing occupational hierarchies proved a major motivation for action on the Copperbelt mines. Seemingly straightforward negotiations around the use of particular tools had far-reaching implications for perceptions of skill, authority, and the dignity of labour. The masculine status of white mineworkers as men able to exercise a degree of authority and autonomy in the workplace and able to support their families was under assault. Gender roles were challenged as men went months without wages. What was at stake in the strike was, according to Jack Purvis, "our dignity and pride... and no employer has the right to flout, or attempt to belittle, that pride" (Northern News, 11 
October 1958). Militancy was driven primarily by those skilled workers with the most to lose and who fought to defend their place in the occupational hierarchy.

The strike demonstrated the limits of control which an essentially expatriate workforce could enforce over the industry. Despite the important jobs they performed on the mines and with the white community mobilised behind them, white artisans failed to prevent restructuring. Their defeat, and the previous defeat of the AMU during 1956, ensured that RAA and RST had a relatively free hand to reorganise the mines as they saw fit prior to Zambian independence in 1964. The sense of collective identity and interests dissipated in the face of defeat. Strikes by white mineworkers - some of them lengthy - continued to plague the industry until the late 1960s but they were never again able to take coordinated action and shut down the entire Copperbelt. This was a moment of transition as the Copperbelt's white workforce became more like the modern-day expatriate workforces in the mining industry today.

The late 1950s was a period of high tensions on the Copperbelt, and the protracted negotiations over the removal of the industrial colour bar discussed in the existing literature was only a part of this. The mining companies, in the face of falling copper prices, sought to cut costs by tackling their expensive white workforce. White mineworkers had firm convictions that the copper industry should be run primarily for their benefit and sought to struggle against their white employers to defend this conviction. This was a struggle which, involving as it did a defence of the colour bar, clearly had a racial dimension. Yet it was the demarcation of artisans' work that white mineworkers took their stand over, not the colour bar: their main opponent was not African mineworkers but the companies that employed them.

The length of the strike, the scale of the community mobilisation, and the anger it aroused all attest to the importance placed on this stand by people at the time. Restructuring the white workforce was an important moment in the history of the mining industry and it is one that has not hitherto been acknowledged in the voluminous literature on the Copperbelt mines and their workforces. This top-down fragmentation of existing work practices prefigured the way in which the colour bar was lifted in the 1960s. Skilled jobs performed by whites were fragmented into several lower-paid jobs, rather than made available to African mineworkers (Brown, 1966). White artisans, their trade union, and the way of life they sought to defend all vanished. 


\section{Acknowledgements}

This paper was initially a sub-section of my doctoral thesis and was developed at panels on social and political extractive communities organised by Miles Larmer and Vito Laterza at the European Conference on African Studies in July 2015 and the African Studies Association of the UK conference in September 2016. I would like to thank Miles Larmer, Gavin Williams and the two anonymous reviewers for their helpful feedback on my paper. This work was partially funded by the Beit Fund at the University of Oxford.

\section{References}

\section{Primary Material}

Benson, A., 11 November 1958. Letter to Keith Acutt and Ronald Prain. The National Archives, London, CO 1015/2035.

Bromwich, E.C., Davidson, J.M., 26 February 1958. The European Wage Structure on the Copperbelt. Zambia Consolidated Copper Mines Archive, Ndola, 17.4.4C.

Brown, R., 1966. Report of the Commission of Inquiry into the Mining Industry 1966. Government Printers, Lusaka.

Central Statistical Office, 1960. Census of Publication 1956. Salisbury.

Central Statistical Office, December 1963. European Consumer Price Index: Weighted Average for Northern Rhodesia, Federation of Rhodesia and Nyasaland Monthly Digest of Statistics. Salisbury.

Chamber of Mines, 4 October 1944. Arbitration Tribunal: Evidence of the Copper Mining Companies. Zambia Consolidated Copper Mines Archive, Ndola, 3.8.1A. 
Chamber of Mines, 1957. Year Book. Kitwe.

Chamber of Mines, 31 March 1958. Quarterly Report on Industrial Relations. Zambia Consolidated Copper Mines Archive, Ndola, 17.4.4C.

Chamber of Mines, 1 July 1958. Telegram to Anmercosa and Roselite Salisbury. Zambia Consolidated Copper Mines Archive, Ndola, 11.1.2A.

Chamber of Mines, 22 July 1958. Letter from A.C. Annfield, Secretary, Chamber of Mines to General Secretary, Northern Rhodesia Mine Workers' Union. Zambia Consolidated Copper Mines Archive, Ndola, 11.1.2A.

Chamber of Mines, 29 August 1958. Telegram to Anmercosa and Roselite Salisbury. Zambia Consolidated Copper Mines Archive, Ndola, 11.1.2A.

Chamber of Mines, 10 September 1958. Telegram to Anmercosa and Roselite Salisbury. Zambia Consolidated Copper Mines Archive, Ndola, 11.1.2A.

Chamber of Mines, 11 September 1958. Telegram to Anmercosa and Roselite Salisbury. Zambia Consolidated Copper Mines Archive, Ndola, 11.1.2A.

Chamber of Mines, 12 September 1958. Job Demarcation Dispute. Zambia Consolidated Copper Mines Archive, Ndola, 11.1.2A.

Chamber of Mines, 16 September 1958. Telegram to Anmercosa and Roselite Salisbury. Zambia Consolidated Copper Mines Archive, Ndola, 11.1.2A.

Chamber of Mines, 24 September 1958. Telegram to Anmercosa and Roselite Salisbury. Zambia Consolidated Copper Mines Archive, Ndola, 11.1.2A.

Chamber of Mines, 17 October 1958. Telegram to Anmercosa and Roselite Salisbury. Zambia Consolidated Copper Mines Archive, Ndola, 11.1.2A.

Chamber of Mines, 19 October 1958. Telegram to Anmercosa and Roselite Salisbury. Zambia Consolidated Copper Mines Archive, Ndola, 11.1.2A.

Chamber of Mines, 3 November 1958. Agreement signed on Monday $3^{\text {rd }}$ November by the Governor and representatives of Government, the Companies and the Union. Modern Records Centre, University of Warwick, Coventry, MSS. 292/968.1/11. 
Chamber of Mines, 15 November 1958. The Jobs Dispute and the Press. Zambia Consolidated Copper Mines Archive, Ndola, 11.1.2A.

Chamber of Mines, 25 November 1958. Notes on the course of the demarcation dispute. Zambia Consolidated Copper Mines Archive, Ndola, 11.1.2A.

Chamber of Mines, 1959. Year Book. Kitwe.

Chamber of Mines, 1962. Year Book. Kitwe.

Colonial Office, September 1958. Extract from Northern Rhodesian Intelligence Report. The National Archives, London, CO 1015/2035.

Colonial Office, December 1958. Particulars of restrictions orders made under Emergence (Transitional Provisions) Ordinance. The National Archives, London, CO $1015 / 1451$.

Colonial Office, 25 September 1958. Copperbelt Strike: Position as at 25 September 1958. The National Archives, London, CO 1015/2035.

Handford, H. 19 April 1959. Untitled Statement. Zambia Consolidated Copper Mines Archive, Ndola, 11.1.2A.

Holleman, J.F. and Biesheuvel, S., 1960. The Attitudes of White Mining Employees towards Life and Work on the Copperbelt. Part I: A Social Psychological Study. National Institute for Personnel Research, Johannesburg.

Hood, W., 8 September 1958. Letter to Vincent Tewson. Modern Records Centre, University of Warwick, Coventry, MSS. 292/968.1/11.

Mufulira Mine, 19 August 1955. Memorandum from Personnel Manager to General Manager. Zambia Consolidated Copper Mines Archive, Ndola, 10.5.8D.

Northern News, 4 August 1958. 'Shop Stewards Call for Rejection of Peace Plan'. Northern News, 12 August 1958. 'Union Hangs Fire on Overtime Ban'.

Northern News, 15 August 1958. 'He may be Test Case'.

Northern News, 2 September 1958. 'Dispute is Declared by Union over Pay' 
Northern News, 3 September 1958. Letter from R.K. Lloyd.

Northern News, 5 September 1958. 'Top Union Men Rush to Avert Strike'.

Northern News, 9 September 1958. 'Government Step-in is Sought'.

Northern News, 12 September 1958. Letter from Spero Meljora.

Northern News, 16 September 1958. ' $£ 500,000$ Threat May Face Companies’.

Northern News, 18 September 1958. 'Copperbelt Wives Back Striking Mineworkers'.

Northern News, 27 September 1958. Letter from 'Can Take It'.

Northern News, 1 October 1958. Letter from 'Miner's Wife'.

Northern News, 9 October 1958. 'Strike Families in Trouble may be 'Too Proud to Seek Charity".

Northern News, 11 October 1958. 'Message to Members'.

Northern News, 13 October 1958. 'Strikers' families tuck in to gift of bananas'.

Northern News, 16 October 1958. Letter from ‘Fair Play’.

Northern News, 18 October 1958. 'Women play 'Santa' to strike-hit families'.

Northern News, 21 October 1958a. 'Halt the Strike'.

Northern News, 21 October 1958b. Letter from 'Corrupt'.

Northern News, 22 October 1958. "Act now' Demand to Govt. by Copperbelt Businessmen'.

Northern News, 28 October 1958. 'Strike: Merchants Praised'.

Northern News, 29 October 1958a. 'Lightning Jimmy' is in there, swinging for the mineworkers'.

Northern News, 29 October 1958b. 'Copperbelt Women Unite to Fight Strike'.

Northern News, 31 October 1958. Letter from 'Mineworker'.

Northern News, 4 November 1958. 'Decisive Vote Ends Strike'. 
Northern Rhodesia Mine Workers' Union, 24 May 1958. Minutes of Liaison Committee meeting held in 'Union House'. Miners' International Federation, Box 359. International Institute of Social History, Amsterdam.

Northern Rhodesia Mine Workers' Union, 12 August 1958. Notice at Mufulira Mine. Zambia Consolidated Copper Mines Archive, Ndola, 11.1.2A.

Northern Rhodesia Mine Workers' Union, 28 August 1958. Modern Records Centre, University of Warwick, Coventry, MSS. 292/968.1/11.

Northern Rhodesia Mine Workers' Union, 29 September 1958. Annual General Council Meeting. Modern Records Centre, University of Warwick, Coventry, MSS. 292/968.1/11.

Northern Rhodesia Mine Workers' Union, 17 October 1958. Circumstances Leading up to the Present Copperbelt Strike. Historical Papers Archive, University of the Witwatersrand, Johannesburg, AH 1426 Ea6.

Prain, R., 10 December 1958, Letter to Governor Arthur Benson. The National Archives, London, CO 1015/2035.

Rhokana Review, June 1958. 'May Day Tradition at Nkana'.

Roan Antelope, August 1958. 'Departmental News'.

Roan Antelope Copper Mines, 18 September 1958. Minutes of a meeting with representatives of the Mine Workers' Union. Zambia Consolidated Copper Mines Archive, Ndola, 11.1.2A.

Roan Branch, 19 September 1958. Branch Newsletter No. 1. Zambia Consolidated Copper Mines Archive, Ndola, 11.1.2A.

Roan Branch, 7 October 1958. Branch Newsletter No. 5. Zambia Consolidated Copper Mines Archive, Ndola, 11.1.2A.

Roan Branch, 22 October 1958. Branch Newsletter No. 8. Zambia Consolidated Copper Mines Archive, Ndola, 11.1.2A.

Roan Consolidated Mines, 1978, Zambia's Mining Industry: The First Fifty Years. Public Relations Department, Ndola. 
Roselite Salisbury, 22 October 1958. Telegram to Chamber of Mines. Zambia Consolidated Copper Mines Archive, Ndola, 11.1.2A.

The Guardian, 17 August 1957. 'European mine union split?'.

Trade Union Council of South Africa, 22 October 1958. Circular to Affiliated Unions. Historical Papers Archive, University of the Witwatersrand, Johannesburg, AH 1426 Ea6.

\section{Secondary Literature}

Berger, E.L., 1974. Labour, Race, and Colonial rule: the Copperbelt from 1924 to independence. Clarendon Press, Oxford.

Brown, C., 2006. Race and the Construction of Working-Class Masculinity in the Nigerian Coal Industry: The Initial Phase, 1914-1930. International Labor and Working-Class History. 69, 35-56.

Burawoy, M., 1972. The Colour of Class on the Copper Mines: From African advancement to Zambianization. Manchester University Press, Manchester.

Butler, L., 2007. Copper Empire: Mining and the Colonial State in Northern Rhodesia, c.1930-64. Palgrave Macmillan, Basingstoke.

Cancilla Martinelli, P., 2009. Undermining Race: Ethnic Identities in Arizona Copper Camps, 1880-1920. University of Arizona Press, Tucson, 2009.

Coleman, F. 1971. The Northern Rhodesia Copperbelt 1899-1962. Manchester University Press, Manchester.

Daniel, P., 1979. Africanisation, Nationalisation and Inequality: Mining labour and the Copperbelt in Zambian development. Cambridge University Press, Cambridge.

Dunn, C., 1959. Central African Witness. Victor Gollancz, London.

Katz, E.N., 1976. A Trade Union Aristocracy: A history of white workers in the Transvaal and the general strike of 1913. University of the Witwatersrand, Johannesburg. 
Kay, G. 1967. A Social Geography of Zambia: A survey of population patterns in a developing country. University of London Press, London.

Krikler, J., 2005. White Rising: The 1922 Insurrection and Racial Killing in South Africa. Manchester University Press, Manchester.

Lankton, L., 1991. Cradle to Grave: Life, work, and death at the Lake Superior copper mines. Oxford University Press, New York.

Larmer, M., 2007. Mineworkers in Zambia: Labour and Political Change in PostColonial Africa. Taurus Academic Studies, London.

LeCain, T.J., 2009. Mass Destruction: The men and giant mines that wired America and scarred the planet. Rutgers University Press, London.

Mhone, G.C.Z., 1982. The Political Economy of a Dual Labour market in Africa: The copper industry and dependency in Zambia, 1926-69. Associated University Press, London.

Parpart, J., 1986. The Household and the Mine Shaft: Gender and Class Struggles on the Zambian Copperbelt, 1926-64. Journal of Southern African Studies. 13 (1), 35-56.

Perrings, C., 1980. A Moment in the 'Proletarianization' of the New Middle Class: Race, Value and the Division of Labour in the Copperbelt, 1946-1966. Journal of Southern African Studies. 6 (2), 183-213.

Phimister, I., 2011. Workers in Wonderland? White Miners and the Northern Rhodesian Copperbelt, 1946-1962. South African Historical Journal. 63 (2), 183-233.

Sakala, F., 2011. A Social History of Women in the Mine Compounds of the Zambian Copperbelt During the Colonial Period. Ph.D. thesis, Essex University.

Stead, J., 1987. Never the Same Again: Women and the Miners' Strike, 1984-85. Women's Press, London.

Stewart, P. 2013. 'Kings of the Mine': Rock Drill Operators and the 2012 Strike Wave on South African Mines. South African Review of Sociology. 44 (3), 42-63. 